\title{
Transvaginal Approach for Nongynecologic Intraperitoneal Procedures
}

\author{
José F. Noguera1* , Gonzalo Martín1, José M. Muñoz², Antonio Melero33, Raúl Sánchez³, \\ Javier Valdivia ${ }^{4}$, Marcos Bruna' ${ }^{1}$, Antonio Salvador ${ }^{1}$, Cristóbal Zaragoza ${ }^{3}$ \\ ${ }^{1}$ Minimally Invasive Therapies Unit, Consorcio Hospital General Universitario de Valencia, Valencia, Spain \\ ${ }^{2}$ Department of Surgery, Hospital Son Llàtzer, Palma, Spain \\ ${ }^{3}$ Department of Surgery, Consorcio Hospital General Universitario de Valencia, Valencia, Spain \\ ${ }^{4}$ Department of Surgery, Hospital Virgen de las Nieves, Granada, Spain \\ Email: ${ }^{*}$ drjfnoguera@hotmail.com
}

Received 29 October 2014; revised 28 November 2014; accepted 12 December 2014

Copyright (C) 2014 by authors and Scientific Research Publishing Inc.

This work is licensed under the Creative Commons Attribution International License (CC BY).

http://creativecommons.org/licenses/by/4.0/

(c) (i) Open Access

\section{Abstract}

The minimally invasive surgery through natural orifices has revolutionized the laparoscopic surgery for abdominal procedures. The use of the vaginal approach is not new for gynecologists but it is a new concept for the non-gynecological laparoscopic surgeons. The use of this new approach has been used to perform some procedures and to extract specimens after a laparoscopic surgery, but we don't know exactly the number of procedures performed until today. There are few papers with clinical experience and a lot of philosophical papers about NOTES. Our aim is to know how and how often we are using this new approach for non-gynecological abdominal minimally invasive procedures. With the revision of the PubMed publications we obtained a total of 268 articles, of which 125 were included in the analysis $(46.64 \%)$. Cholecystectomy was the procedure more usually performed: there is a large clinical experience with a total of 2432 transvaginal cholecystectomies. Bariatric surgery, colectomy and appendectomy have been other surgical procedures with some clinical experience in the use of the transvaginal approach. Analyzing the publications on transvaginal approach, we observed that the use of the vaginal route for non-gynecological abdominal surgery was not anecdotal, with accumulative experience of more than 3000 patients reported in published studies. The use of the vaginal route has shown its safety, obtaining some additional benefits such as the aesthetic and the faster functional recovery. Dyspareunia, one of the most feared, has not been reported in studies as a concern to consider.

\section{Keywords}

Transvaginal Surgery, Endoscopic Surgery, Laparoscopy, Flexible Endoscopy

\footnotetext{
${ }^{*}$ Corresponding author.
}

How to cite this paper: Noguera, J.F., Martín, G., Muñoz, J.M., Melero, A., Sánchez, R., Valdivia, J., Bruna, M., Salvador, A. and Zaragoza, C. (2014) Transvaginal Approach for Nongynecologic Intraperitoneal Procedures. International Journal of Clinical Medicine, 5, 1417-1429. http://dx.doi.org/10.4236/ijcm.2014.521180 


\section{Introduction}

Minimally invasive surgery (MIS) has suffered one of its great revolutions in the last decade. The advent of new trends and concepts has brought us a new stage in the MIS. The use of the transvaginal route to perform a surgical procedure or to remove a surgical specimen is not new. In fact, culdoscopy and transvaginal extraction of surgical specimens has been performed before but we become aware of its importance with the arrival of the concept of Natural Orifice Translumenal Endoscopic Surgery (NOTES).

The emergence of NOTES has meant a revolution for all, the laparoscopic surgeons, endoscopists, industry and of course, for patients. Keeping in line with this transformation of MIS some techniques that were forgotten such as the minilaparoscopy, needlescopic surgery, culdolaparoscopy and suture techniques in flexible endoscopy have awakened. Although, from the first clinical application in 2007 to the present day there have been several applications of NOTES, it has been more a revolution in the field of design ideas and instrumentation than in the field of clinical applications. Few teams have implemented these techniques in their daily procedures. These approaches have been in the hands of selected teams who have combined their interest and expertise to support the industry that has given them the equipment needed to develop the technique [1]-[5].

We have learned soon that the transvaginal approach would be the most applied route by virtue of its clinical safety and easy access for opening and closing viscerotomy. The transgastric approach presented some problems due to the entry trough the gastric wall and the prevention of peritoneal contamination. But, its main drawback was getting a secure closure, difficult procedure using only flexible endoscopy. The transvesical approach had the size limitation for the introduction of instrumentation and specimen extraction so it was considered as a way for support from the pelvis, in combination with other approaches. Regarding the transrectal approach, it soon proved to be an alternative for rectal and distal colonic procedures, not as a way to access the peritoneal cavity and to perform intraperitoneal procedures.

But the transvaginal approach showed safe with the previous experience of gynecological surgery. Thanks to this experience, we have learned that the general complication rate was low and with easy resolution as well as serious complications like rectal, bladder or vascular injury was extremely low [6]-[8]. Besides, the vaginal wall opening and closing was simple for surgeons with some experience in pelvic surgery.

The ease of exploration, cleaning, closure and solution of potential problems, has become the transvaginal approach the route of excellence. The point of entry through the vagina in the posterior fornix should be chosen carefully to avoid pelvic or uterine injury. The entry into the pelvis from the vagina can be supported directly with trocars $15 \mathrm{~cm}$ in length, thereby, facilitating the entry and withdrawal of several instruments and avoiding trauma to the vaginal wall. For this entry it is advisable to use a 3 - $5 \mathrm{~mm}$ optic from the navel to check the safety. After the procedure, the surgical specimen extraction can be done directly or protected with plastic bag. The closure after extraction is a directly comfortable and easy closure performed by the surgeon.

Currently we are using the vaginal access combined with conventional laparoscopy for the specimen removal avoiding the assistance laparotomy, or as accessory entryport to help in a laparoscopic approach [9]-[11]. Employing this access as a working channel we can introduce either the flexible endoscope, which carries the internal working channel, or rigid instrumentation. In some surgical procedures with transvaginal extraction the surgical technique does not differ significantly to laparoscopy (esplenectomy, adrenalectomy, sleeve gastrectomy...); but in colorectal surgery we are forced to change the modality of anastomosis. In right colectomy we are required to perform intracorporeal anastomosis and in left colectomy to do a transvaginal assistance.

Either way, we should be very judicious and cautious to indicate transvaginal instrumentation. A proper clinical investigation should be performed to rule out any pelvic and gynecological disease. A pelvic examination is mandatory to ensure the integrity of the functional anatomy and to review additional examinations for unsuspected alterations which discourage this approach. Although the most feared complication is dyspareunia it has not been reported with a significant increase in the general population. Other postoperative problems related to sexuality and fertilization would be more conditioned by some postoperative complications that the transvaginal approach itself.

The uneven spread of the transvaginal approach in surgical procedures creates a problem for us to know the real implementation of this approach. To know the extent of use of the transvaginal approach we have performed a comprehensive review and analysis of the literature.

\section{Material and Methods}

Since there has been an uneven implementation of the transvaginal approach and clinical application has been 
shared by various surgical specialties, it is difficult to know the use that is being made of this NOTES approach in non-gynecological surgery. In order to know the acceptance that has had the transvaginal approach in non-gynecological abdominal surgery a comprehensive review through the PubMed database with the criteria in Table 1 was performed.

From the resulting articles some originals were removed. Duplicated articles, opinion articles, articles that did not deal with surgical techniques, articles with some NOTES approach different to vaginal one and articles treating gynecological surgery, were eliminated of the search. We preserved the articles that provided information on the use of the vaginal approach in non-gynecological abdominal surgery. These papers were divided into four categories: experimental studies, case reports, prospective clinical series (more than 10 patients) and clinical trials (randomized clinical trials only). In turn they were divided in relation to the pathology and surgical technique which they were intended.

\section{Results}

We obtained a total of 268 articles, of which 125 met the criteria for inclusion in the analysis (46.64\%). The category distribution is shown in Table 2. Among the articles we found two international registries [12] [13]; they have forced to remove some articles with reported cases to the registry and also independently published in papers with individual results.

Table 1. Search terms in PubMed. Term trasnsvaginal as isolated and combined with the other terms.

\begin{tabular}{cc}
\hline Transvaginal & \\
\hline & +Surgery \\
& + Digestive surgery \\
+ Natural orifice endoscopic surgery & + Adrenalectomy \\
& + Appendectomy \\
& + Bariatric surgery \\
& + Cholecystectomy \\
& + Colectomy \\
& + Gastrectomy \\
& + Liver resection \\
& + Nephrectomy \\
& + Splenectomy \\
\hline
\end{tabular}

Table 2. Distribution of articles in different categories of analysis.

\begin{tabular}{|c|c|c|c|c|c|c|}
\hline & Experimental & Clinical cases & Case series & Clinical trials & Total studies & Total patients \\
\hline Adrenalectomy & 2 & 1 & 1 & 0 & 4 & 12 \\
\hline Appendectomy & 1 & 4 & 3 & 0 & 8 & 84 \\
\hline Bariatric surgery & 1 & 2 & 2 & 0 & 5 & 222 \\
\hline Cholecystectomy & 12 & 15 & 26 & 3 & 56 & 2432 \\
\hline Colectomy & 0 & 10 & 8 & 0 & 18 & 211 \\
\hline Gastrectomy & 1 & 2 & 0 & 0 & 3 & 6 \\
\hline Liver resection & 0 & 2 & 0 & 0 & 2 & 2 \\
\hline Nephrectomy & 10 & 10 & 3 & 0 & 23 & 59 \\
\hline Splenectomy & 0 & 3 & 0 & 0 & 3 & 3 \\
\hline Total & 27 & 49 & 43 & 3 & 122 & 3031 \\
\hline
\end{tabular}


We can observe that the cholecystectomy procedure has been the target for the development of the transvaginal approach in intraperitoneal surgery. In all records of NOTES surgery, cholecystectomy has brought more than 75\% of the entries (93\% in EuroNOTES, 85\% in German and 74\% in the Latin American registry). Transvaginal approach for cholecystectomy was performed in two ways: by direct approach without transmural abdominal support (rarely) or by 3 or $5 \mathrm{~mm}$ optical visual support placed in the navel to access safely through the posterior vaginal fornix (most cases). In relation to the instrumentation we can describe four different procedures. The pure NOTES: with two flexible endoscopes from the vagina or from the vagina and stomach. The hybrid NOTES: combining flexible and rigid endoscopy with a transvaginal or transmural access. The rigid NOTES, rigid instruments that combine straight, pre-curved and articulated forceps. The last procedure is the specimen removal through the vagina (NOSE-Natural Orifice Specimen Extraction) whiles the cholecystectomy procedure was performed using laparoscopic skills. In all clinical applications the vaginal closure was performed externally by direct absorbable suturing. The laparoscopic closure possibility exists but requires three transmural trocars therefore it has not been used in cholecystectomy.

In experimental studies the focus has been mainly on transgastric and transvaginal approaches, sometimes with transvesical support. Cholecystectomy has been $44.4 \%$ of surgical techniques addressed in the work with animals, closely followed by nephrectomy (37\%). Experimentation in transgastric approaches mainly focused on creating a secure method of opening and closing of the stomach as well as the reproducibility of cholecystectomy from a supramesocolic route. In cases of transvaginal access, the focus was mainly on the reproducibility of surgical maneuvers using the flexible endoscope.

In terms of clinical application we found 15 publications of clinical cases: 26 clinical series but only 3 clinical trials. Clinical trials represent only $6.8 \%$ of the publications on transvaginal cholecystectomy in humans, but clinical series have included a large number of patients. So there is a large clinical experience with a total of 2432 transvaginal cholecystectomies performed. The safety and efficacy data emanating from all these studies show us the non-inferiority of transvaginal approach with respect to conventional laparoscopy. In all these papers the authors argue that we are in a transition phase from the laparoscopy to the pure NOTES needing a technological evolution that allows us to achieve secure access through natural orifice [14]-[70].

It seemed that the appendectomy was to be the second technique performed in the transvaginal approach but, surprisingly, bariatric surgery was the second most common after cholecystectomy. This broad experience, with a cumulative total of 222 patients, is due to the contribution of two clinical series: Buesing et al. with 200 patients, and Couillard et al., 20 patients. The use of flexible endoscope has been anecdotal in these procedures, being in most cases the vaginal route used for instrumental assistance of a rigid laparoscopic procedure.

Sometimes the use of the vagina has been limited to extract the piece of tubular gastrectomy. Restrictive procedures have been used in natural orifice approaches, by virtue of its lower complexity than the malabsorptive techniques. Specifically, the gastric sleeve has been the most realized, as it is a feasible technique with endoscopic stapler that can be applied from the vagina [71]-[75].

More interesting has been the experience of the transvaginal approach in colorectal surgery although the overall number of patients enrolled was lower (211 patients). It is the experience of a greater number of working groups with more variety of procedures and the colorectal transvaginal approach opened the door to another promising approach, the transanal approach TAMIS (Trans Anal Minimally Invasive Surgery). Most experience in this type of surgery comes from case-series grouped in most studies of 10 to 20 patients, except in Park et al. series including 68 patients. It is notable that, as in bariatric surgery, prospective comparative studies have not been made. The transvaginal route was used in colorectal surgery primarily for extracting the specimen. In some cases there had been any surgical gesture from the vagina, as the section of the mesenteric vessels, colorectal section or assistance to the preparation of the anastomosis. In these procedures, the use of rigid instrumental from vaginal access is the standard, without experience in the use of the flexible endoscope.

The most common procedure was right hemicolectomy, being the standard procedure the intracorporeal anastomosis and transvaginal specimen extraction. All authors agree in emphasizing that the removal of assistance laparotomy is the great advantage of transvaginal assistance, eliminating the morbidity resulting from this laparotomy, mainly surgical wound infections and postoperative ventral hernias [76]-[92].

An appendectomy was the second procedure, after cholecystectomy, which has been treated with the intention of NOTES surgery as pure as possible. Only 8 articles were found dealing transvaginal appendectomy, of which 7 are cases and clinical series and only one of them is a prospective comparative study with 40 patients. Experimental studies have compared the transgastric and transvaginal approach with flexible endoscope, finding 
that appendectomy is feasible in a porcine model with flexible endoscope, making it easier to access from the stomach than from the pelvis. In terms of clinical application, appendectomy was performed in 50 patients incidentally at laparoscopic hysterectomy with transvaginal assistance, without any significant incidents reported.

An appendectomy for acute appendicitis was made by transvaginal approach with minimal parietal support in 4 clinical studies (case reports and small series of less than 10 patients). In some cases the authors used the flexible endoscope and in others rigid instruments, with vaginal extraction and mini laparoscopy support from the abdominal wall in all of them. Data reported showed to be a safe approach and to offer a better postoperative comfort that conventional laparoscopy. The only prospective clinical study for appendectomy for acute appendicitis has been reported in 2012 by Roberts et al., comparing 18 transvaginal appendectomies versus 22 laparoscopic approaches with a similar incidence of adverse events and one conversion to laparoscopic surgery in the transvaginal group. The transvaginal group showed a faster recovery and less postoperative pain [93]-[100].

Tansvaginal nephrectomy has been the technique with more experimental publications. In 2002 was published the first experimental study in porcine model trying an exclusive transvaginal nephrectomy, followed by subsequent experimental contributions working with flexible endoscopes in isolation or combined with transgastric approach or parietal access. As we found for other techniques, rigid instrumental participation through the vagina and instrumental support through the abdominal wall were widely used to facilitate maneuverability and reduce surgical time. In some studies, the authors tested the use of a single-port device through the vagina.

At the clinical experience, nephrectomies were initiated with hybrid transvaginal approach. In most cases with the help of two or more parietal trocars and for benign causes, but showing also safety and reproducibility in cases of renal carcinoma. The rise of the single-port devices have conduced to some combined experiences of transumbilical single port and transvaginal access. But the most interesting clinical application of transvaginal approach is the surgery on the living donor kidney transplant. In the living donor we must look for the least invasive surgery while we preserve the extracted graft in the optimal conditions as in the conventional surgery. The transvaginal approach for nephrectomy and renal extraction has been very beneficial to the donor, with less pain and faster functional recovery, while preserving the quality of the graft, with the only slight increase in surgical time in the donor [101]-[123].

In the remaining surgical indications clinical experience has been limited. In 12 published articles we can obtained all the experience in transvaginal adrenalectomy (12), gastrectomy (2), splenectomy (3) and hepatectomy (2). This is an anecdotal application that employs in most cases the rigid instruments trough the vagina or a vaginal extraction of surgical specimens. In some articles the flexible endoscope was used, assessing a better vision than with rigid laparoscope, probably because the organs to be treated were in the supramesocolic space. In this situation, the flexible endoscope offered a better access with closer lighting and better access due to their mobility [124]-[134].

\section{Discussion}

When we exhaustively analyzed the publications on transvaginal approach, we observed that the use of the vaginal route for non-gynecological abdominal surgery was not anecdotal. With clinical experience of more than 3000 patients reported in published studies we can make some reflections on the vaginal approach.

The first is that the use of this route is not uncommon as it may seem at a first assessment. Although the most common techniques have been the cholecystectomy and the bariatric, colorectal and appendiceal surgery, the use of the transvaginal approach has reached to all the techniques in abdominal surgery, albeit in an anecdotal way, just to show that it was feasible.

The second of the reflections is that the use of the vaginal route has not been taxed with a general increase in intra or postoperative complications and has not moved the possible complications of the abdominal wall to the vagina or the pelvis. Dyspareunia, one of the most feared, has not been reported in studies as a concern to consider, given its zero or low incidence, although its appearance should be monitored in the ongoing studies. Endoscopic procedures performed with transvaginal assistance have been as safe and effective as conventional laparoscopy, obtaining some benefits such as the aesthetic and the faster functional recovery.

\section{References}

[1] Kalloo, A.N., Singh, V.K., Jagannath, S.B., et al. (2004) Flexible Transgastric Peritoneoscopy: A Novel Approach to Diagnostic and Therapeutic Interventions in the Peritoneal Cavity. Gastrointestinal Endoscopy, 60, 114-117. http://dx.doi.org/10.1016/S0016-5107(04)01309-4 
[2] Bessler, M., Stevens, P.D., Milone, L., Parikh, M. and Fowler, D. (2007) Transvaginal Laparoscopically Assisted Endoscopic Cholecystectomy: A Hybrid Approach to Natural Orifice Surgery. Gastrointestinal Endoscopy, 66, 12431245. http://dx.doi.org/10.1016/j.gie.2007.08.017

[3] Marescaux, J., Dallemagne, B., Perretta, S., Wattiez, A., Mutter, D. and Coumaros, D. (2007) Surgery without Scars: Report of Transluminal Cholecystectomy in a Human Being. Archives of Surgery, 142, 823-826. http://dx.doi.org/10.1001/archsurg.142.9.823

[4] Fritscher-Ravens, A., Mosse, C.A., et al. (2003) Transluminal Endosurgery: Single Lumen Access Anastomotic Device for Flexible Endoscopy. Gastrointestinal Endoscopy, 58, 585-591. http://dx.doi.org/10.1067/S0016-5107(03)02006-6

[5] Kaehler, G., Grobholz, R., Langner, C., et al. (2006) A New Technique of Endoscopic Full-Thickness Resection Using a Flexible Stapler. Endoscopy, 38, 86-89. http://dx.doi.org/10.1055/s-2005-921181

[6] Ghezzi, F., Raio, L., Mueller, M.D., Gyr, T., Butarelli, M. and Franchi, M. (2002) Vaginal Extraction of Pelvic Masses Following Operative Laparoscopy. Surgical Endoscopy, 16, 1691-1696. http://dx.doi.org/10.1007/s00464-002-9043-Z

[7] Horng, S.G., Huang, K.G., Lo, T.S. and Soong, Y.K. (2004) Bladder Injury after LAVH: A Prospective, Randomized Comparison of Vaginal and Laparoscopic Approaches to Colpotomy during LAVH. Journal of the American Association of Gynecologic Laparoscopists, 11, 42-46. http://dx.doi.org/10.1016/S1074-3804(05)60008-4

[8] Teng, F.Y., Muzsnai, D., Perez, R., Mazdisnian, F., Ross, A. and Sayre, J.W. (1996) A Comparative Study of Laparoscopy and Colpotomy for the Removal of Ovarian Dermoid Cysts. Obstetrics Gynecology, 87, 1009-1013. http://dx.doi.org/10.1016/0029-7844(96)00061-0

[9] Rovio, P.H. and Heinonen, P.K. (2006) Transvaginal Myomectomy with Screw Traction by Colpotomy. Archives of Gynecology and Obstetrics, 273, 211-215. http://dx.doi.org/10.1007/s00404-005-0078-y

[10] Gill, I.S., Cherullo, E.E., Meraney, A.M., Borsuk, F., Murphy, D.P. and Falcone, T. (2002) Vaginal Extraction of the Intact Specimen Following Laparoscopic Radical Nephrectomy. Journal of Urology, 167, 238-241. http://dx.doi.org/10.1016/S0022-5347(05)65423-7

[11] Wilson, J.I., Dogiparthi, K.K., Hebblethwaite, N. and Clarke, M.D. (2007) Laparoscopic Right Hemicolectomy with Posterior Colpotomy for Transvaginal Specimen Retrieval. Colorectal Disease, 9, 662. http://dx.doi.org/10.1111/j.1463-1318.2007.01313.x

[12] Zorron, R., Palanivelu, C., Galvãoneto, M.P., Ramos, A., Salinas, G., Burghardt, J., et al. (2010) International Multicenter Trial on Clinical Natural Orifice Surgery-NOTES IMTN Study: Preliminary Results of 362 Patients. Surgical Innovation, 17, 142-158. http://dx.doi.org/10.1177/1553350610370968

[13] Lehmann, K.S., Ritz, J.P., Wibmer, A., Gellert, K., Zornig, C., Burghardt, J., et al. (2010) The German Registry for Natural Orifice Translumenal Endoscopic Surgery: Report of the First 551 Patients. Annals of Surgery, 252, 263-270. http://dx.doi.org/10.1097/SLA.0b013e3181e6240f

[14] Asakuma, M., Perretta, S., Allemann, P., Cahill, R., Con, S.A., Solano, C., Pasupathy, S., Mutter, D., Dallemagne, B. and Marescaux, J. (2009) Challenges and Lessons Learned from NOTES Cholecystectomy Initial Experience: A Stepwise Approach from the Laboratory to Clinical Application. Journal of Hepato-Biliary-Pancreatic Surgery, 16, 249254. http://dx.doi.org/10.1007/s00534-009-0089-3

[15] Auyang, E.D., Hungness, E.S., Vaziri, K., Martin, J.A. and Soper, N.J. (2009) Human NOTES Cholecystectomy: Transgastric Hybrid Technique. Journal of Gastrointestinal Surgery, 13, 1149-1150. http://dx.doi.org/10.1007/s11605-009-0813-y

[16] Becerra Garcia, F.C., Misra, M.C., Bhattacharjee, H.K. and Buess, G. (2009) Experimental Trial of Transvaginal Cholecystectomy: An ex Vivo Analysis of the Learning Process for a Novel Single-Port Technique. Surgical Endoscopy, 23, 2242-2249. http://dx.doi.org/10.1007/s00464-008-0296-z

[17] Bessler, M., Stevens, P.D., Milone, L., Hogle, N.J., Durak, E. and Fowler, D. (2008) Multimedia Article: Transvaginal Laparoscopic Cholecystectomy: Laparoscopically Assisted. Surgical Endoscopy, 22, 1715-1716. http://dx.doi.org/10.1007/s00464-008-9779-1

[18] Bessler, M., Gumbs, A.A., Milone, L., Evanko, J.C., Stevens, P. and Fowler, D. (2010) Video. Pure Natural Orifice Transluminal Endoscopic Surgery (NOTES) Cholecystectomy. Surgical Endoscopy, 24, 2316-2317. http://dx.doi.org/10.1007/s00464-010-0918-0

[19] Branco Filho, A.J., Noda, R.W., Kondo, W., Kawahara, N., Rangel, M. and Branco, A.W. (2007) Initial Experience with Hybrid Transvaginal Cholecystectomy. Gastrointestinal Endoscopy, 66, 1245-1248. http://dx.doi.org/10.1016/j.gie.2007.10.003

[20] Buess, G.F., Misra, M.C., Bhattacharjee, H.K., Becerra Garcia, F.C., Bansal, V.K. and Bermudez, J.R. (2011) SinglePort Surgery and NOTES: From Transanal Endoscopic Microsurgery and Transvaginal Laparoscopic Cholecystectomy to Transanal Rectosigmoid Resection. Surgical Laparoscopy, Endoscopy \& Percutaneous Techniques, 21, e110-e119. http://dx.doi.org/10.1097/SLE.0b013e318218ddaf 
[21] Castro-PÉRez, R., Acosta-GonzÁLez, L.R., Dopico-Reyes, E. and Robaina-Arias, L.E. (2009) MANOS: Transvaginal Cholecystectomies: Preliminary Report. Cirugía Española, 85, 292-297. http://dx.doi.org/10.1016/j.ciresp.2009.01.005

[22] Cho, Y.B., Park, C.M., Chun, H.K., Yi, L.J., Park, J.H., Yun, S.H., Kim, H.C. and Lee, W.Y. (2011) Transvaginal Endoscopic Cholecystectomy Using a Simple Magnetic Traction System. Minimally Invasive Therapy \& Allied Technologies, 20, 174-178. http://dx.doi.org/10.3109/13645706.2010.526911

[23] Cuadrado-Garcia, A., Noguera, J.F., Olea-Martinez, J.M., Morales, R., Dolz, C., Lozano, L., Vicens, J.C. and Pujol, J.J. (2011) Hybrid Natural Orifice Transluminal Endoscopic Cholecystectomy: Prospective Human Series. Surgical Endoscopy, 25, 19-22. http://dx.doi.org/10.1007/s00464-010-1121-z

[24] A Con, S., Solano, C., Kishimoto, G. and Alvarado Dávila, P. (2011) Transvaginal Notes Cholecystectomy in Humans: First Series of Cases in Costa Rica. Revista de Gastroenterología del Perú, 31, 87-90.

[25] Davila, F., Tsin, D.A., Dominguez, G., Davila, U., Jesús, R. and Gomez De Arteche, A. (2009) Transvaginal Cholecystectomy without Abdominal Ports. Journal of the Society of Laparoendoscopic Surgeons, 13, 213-216.

[26] Davila, F.J., Tsin, D.A., Gutierrez, L.S., Lemus, J., Jesus, R., Davila, M.R. and Torres-Morales, J. (2011) Transvaginal Single Port Cholecystectomy. Surgical Laparoscopy, Endoscopy \& Percutaneous Techniques, 21, 203-206. http://dx.doi.org/10.1097/SLE.0b013e3182138fe6

[27] Decarli, L., Zorron, R., Branco, A., Lima, F.C., Tang, M., Pioneer, S.R., Zanin Jr., I., Schulte, A.A., Bigolin, A.V. and Gagner, M. (2008) Natural Orifice Translumenal Endoscopic Surgery (NOTES) Transvaginal Cholecystectomy in a Morbidly Obese Patient. Obesity Surgery, 18, 886-889. http://dx.doi.org/10.1007/s11695-008-9523-X

[28] Decarli, L.A., Zorron, R., Branco, A., Lima, F.C., Tang, M., Pioneer, S.R., Sanseverino, J.I., Menguer, R., Bigolin, A.V. and Gagner, M. (2009) New Hybrid Approach for NOTES Transvaginal Cholecystectomy: Preliminary Clinical Experience. Surgical Innovation, 16, 181-186. http://dx.doi.org/10.1177/1553350609339375

[29] De Sousa, L.H., De Sousa, J.A., De Sousa Filho, L.H., De Sousa, M.M., De Sousa, V.M., De Sousa, A.P. and Zorron, R. (2009) Totally NOTES (T-NOTES) Transvaginal Cholecystectomy Using Two Endoscopes: Preliminary Report. Surgical Endoscopy, 23, 2550-2555. http://dx.doi.org/10.1007/s00464-009-0453-z

[30] Fan, J.K., Tong, D.K., Ho, D.W., Luk, J., Law, W.L. and Law, S. (2009) Systemic Inflammatory Response after Natural Orifice Translumenal Surgery: Transvaginal Cholecystectomy in a Porcine Model. Journal of the Society of Laparoendoscopic Surgeons, 13, 9-13.

[31] Fan, J.K., Tong, D.K., Law, S. and Law, W.L. (2009) Transvaginal Cholecystectomy with Endoscopic Submucosal Dissection Instruments and Single-Channel Endoscope: A Survival Study in Porcine Model. Surgical Laparoscopy, Endoscopy \& Percutaneous Techniques, 19, 29-33. http://dx.doi.org/10.1097/SLE.0b013e3181902ba7

[32] Federlein, M., Borchert, D., Müller, V., Atas, Y., Fritze, F., Burghardt, J., Elling, D. and Gellert, K. (2010) Transvaginal Video-Assisted Cholecystectomy in Clinical Practice. Surgical Endoscopy, 24, 2444-2452. http://dx.doi.org/10.1007/s00464-010-0983-4

[33] Forgione, A., Maggioni, D., Sansonna, F., Ferrari, C., Di Lernia, S., Citterio, D., Magistro, C., Frigerio, L. and Pugliese, R. (2008) Transvaginal Endoscopic Cholecystectomy in Human Beings: Preliminary Results. Journal of Laparoendoscopic \& Advanced Surgical Techniques, 18, 345-351. http://dx.doi.org/10.1089/lap.2007.0203

[34] Gumbs, A.A., Fowler, D., Milone, L., Evanko, J.C., Ude, A.O., Stevens, P. and Bessler, M. (2009) Transvaginal Natural Orifice Translumenal Endoscopic Surgery Cholecystectomy: Early Evolution of the Technique. Annals of Surgery, 249, 908-912. http://dx.doi.org/10.1097/SLA.0b013e3181a802e2

[35] Hensel, M., Schernikau, U., Schmidt, A. and Arlt, G. (2012) Comparison between Transvaginal and Laparoscopic Cholecystectomy-A Retrospective Case-Control Study. Zentralblatt für Chirurgie, 137, 48-54. http://dx.doi.org/10.1055/s-0030-1247332

[36] Hensel, M., Schernikau, U., Schmidt, A. and Arlt, G. (2011) Surgical Outcome and Midterm Follow-Up after Transvaginal NOTES Hybrid Cholecystectomy: Analysis of a Prospective Clinical Series. Journal of Laparoendoscopic \& Advanced Surgical Techniques, 21, 101-106. http://dx.doi.org/10.1089/lap.2010.0508

[37] Horgan, S., Mintz, Y., Jacobsen, G.R., Sandler, B.J., Cullen, J.P., Spivack, A., Easter, D.W., Chock, A., Savu, M.K., Ramamoorthy, S., Bosia, J., Agarwal, S., Lukacz, E., Whitcomb, E., Savides, T. and Talamini, M.A. (2009) Video. NOTES: Transvaginal Cholecystectomy with Assisting Articulating Instruments. Surgical Endoscopy, 23, 1900. http://dx.doi.org/10.1007/s00464-009-0471-x

[38] Horgan, S., Mintz, Y., Jacobsen, G.R., Sandler, B.J., Cullen, J.P., Spivack, A., Easter, D.W., Chock, A., Savu, M.K., Ramamoorthy, S., Bosia, J., Agarwal, S., Lukacz, E., Whitcomb, E., Savides, T. and Talamini, M.A. (2010) Video. Magnetic Retraction for NOTES Transvaginal Cholecystectomy. Surgical Endoscopy, 24, 2322. http://dx.doi.org/10.1007/s00464-010-0954-9

[39] Horváth, S., Gál, I., Rákóczi, I., Jávor, S., Balatonyi, B., Takács, I., Ferencz, A., Ferencz, S. and Wéber, G. (2009) Transvaginal Cholecystectomy in Animal Model: First Series in Hungary. Magyar Sebészet, 62, 120-124. 
http://dx.doi.org/10.1556/MaSeb.62.2009.3.3

[40] Kilian, M., Raue, W., Menenakos, C., Wassersleben, B. and Hartmann, J. (2011) Transvaginal-Hybrid vs. Single-PortAccess vs. "Conventional” Laparoscopic Cholecystectomy: A Prospective Observational Study. Langenbeck's Archives of Surgery, 396, 709-715. http://dx.doi.org/10.1007/s00423-011-0769-8

[41] Linke, G.R., Tarantino, I., Hoetzel, R., Warschkow, R., Lange, J., Lachat, R. and Zerz, A. (2010) Transvaginal RigidHybrid NOTES Cholecystectomy: Evaluation in Routine Clinical Practice. Endoscopy, 42, 571-575. http://dx.doi.org/10.1055/s-0029-1244159

[42] Marescaux, J., Dallemagne, B., Perretta, S., Wattiez, A., Mutter, D. and Coumaros, D. (2007) Surgery without Scars: Report of Transluminal Cholecystectomy in a Human Being. JAMA Surgery, 142, 823-826. http://dx.doi.org/10.1001/archsurg.142.9.823

[43] Mofid, H. and Zornig, C. (2008) Combined Transvaginal Trans-Umbilical Cholecystectomy Using Fixed Instruments. Der Chirurg.

[44] Navarra, G., Rando, L., La Malfa, G., Bartolotta, G. and Pracanica, G. (2009) Hybrid Transvaginal Cholecystectomy: A Novel Approach. American Journal of Surgery, 197, e69-e72. http://dx.doi.org/10.1016/j.amjsurg.2008.07.059

[45] Niu, J., Song, W., Yan, M., Fan, W., Niu, W., Liu, E., Peng, C., Lin, P., Li, P. and Khan, A.Q. (2011) Transvaginal Laparoscopically Assisted Endoscopic Cholecystectomy: Preliminary Clinical Results for a Series of 43 Cases in China. Surgical Endoscopy, 25, 1281-1286. http://dx.doi.org/10.1007/s00464-010-1360-z

[46] Noguera, J.F., Cuadrado, A., Dolz, C., Olea, J.M., Morales, R., Vicens, C. and Pujol, J.J. (2009) Non-Randomised, Comparative, Prospective Study of Transvaginal Endoscopic Cholecystectomy versus Transparietal Laparoscopic Cholecystectomy. Cirugía Española, 85, 287-291. http://dx.doi.org/10.1016/j.ciresp.2009.02.003

[47] Palanivelu, C., Rajan, P.S., Rangarajan, M., Parthasarathi, R., Senthilnathan, P. and Praveenraj, P. (2008) Transumbilical Flexible Endoscopic Cholecystectomy in Humans: First Feasibility Study Using a Hybrid Technique. Endoscopy, 40, 428-431. http://dx.doi.org/10.1055/s-2007-995742

[48] Palanivelu, C., Rajan, P.S., Rangarajan, M., Prasad, M., Kalyanakumari, V., Parthasarathi, R. and Senthilnathan, P. (2009) NOTES: Transvaginal Endoscopic Cholecystectomy in Humans-Preliminary Report of a Case Series. American Journal of Gastroenterology, 104, 843-847. http://dx.doi.org/10.1038/ajg.2009.1

[49] Perko, Z., Mimica, Z., Stipić, R., Radonić, V., Cala, Z., Bakotin, T., Kraljević, J., Strinić, T., Jakus, I.A. and Simunić, M. (2009) Transvaginal Laparoscopically Assisted Cholecystectomy: A First Croatian Experience. Lijecnicki Vjesnik, 131, 100-101.

[50] Pugliese, R., Forgione, A., Sansonna, F., Ferrari, G.C., Di Lernia, S. and Magistro, C. (2010) Hybrid NOTES Transvaginal Cholecystectomy: Operative and Long-Term Results after 18 Cases. Langenbeck's Archives of Surgery, 395, 241-245. http://dx.doi.org/10.1007/s00423-009-0528-2

[51] Ramos, A.C., Murakami, A., Galvão Neto, M., Galvão, M.S., Silva, A.C., Canseco, E.G. and Moyses, Y. (2008) NOTES Transvaginal Video-Assisted Cholecystectomy: First Series. Endoscopy, 40, 572-575. http://dx.doi.org/10.1055/s-2008-1077398

[52] Roberts, K.E., Shetty, S., Shariff, A.H., Silasi, D.A., Duffy, A.J. and Bell, R.L. (2011) Transvaginal NOTES Hybrid Cholecystectomy. Surgical Innovation, 19, 230-235.

[53] Rossi, P., Bugiantella, W., Graziosi, L., Cavazzoni, E. and Donini, A. (2008) Transvaginal Laparoscopically Assisted Endoscopic Cholecystectomy: Report of 3 Cases. Gastrointestinal Endoscopy, 68, 1226-1228. http://dx.doi.org/10.1016/j.gie.2008.03.1060

[54] Rudiman, R. and Wiradisuria, E. (2009) Initial Experience with Laparoscopic-Assisted Transvaginal Cholecystectomy: A Hybrid Approach to Natural Orifice Surgery. International Surgery, 94, 258-261.

[55] Sánchez-Margallo, F.M., Asencio, J.M., Tejonero, M.C., Pérez, F.J., Sánchez, M.A., Usón, J. and Pascual, S. (2008) Technical Feasibility of Totally Natural Orifice Cholecystectomy in a Swine Model. Minimally Invasive Therapy \& Allied Technologies, 17, 361-364. http://dx.doi.org/10.1080/13645700802528199

[56] Sánchez-Margallo, F.M., Asencio Pascual, J.M., Del Carmen Tejoneroalvarez, M., Sánchez Hurtado, M.A., Pérez Duarte, F.J., Usón Gargallo, J. and Sánchez-Gijón, S.P. (2009) Training Design and Improvement of Technical Skills in the Transvaginal Cholecystectomy (NOTES). Cirugía Española, 85, 307-313. http://dx.doi.org/10.1016/j.ciresp.2009.02.004

[57] Salinas, G., Saavedra, L., Agurto, H., Quispe, R., Ramírez, E., Grande, J., Tamayo, J., Sánchez ,V., Málaga, D. and Marks, J.M. (2010) Early Experience in Human Hybrid Transgastric and Transvaginal Endoscopic Cholecystectomy. Surgical Endoscopy, 24, 1092-1098. http://dx.doi.org/10.1007/s00464-009-0733-7

[58] Satgunam, S., Miedema, B., Whang, S. and Thaler, K. (2012) Transvaginal Cholecystectomy without Laparoscopic Support Using Prototype Flexible Endoscopic Instruments in a Porcine Model. Surgical Endoscopy, 26, 2331-2338. 
[59] Scott, D.J., Tang, S.J., Fernandez, R., Bergs, R., Goova, M.T., Zeltser, I., Kehdy, F.J. and Cadeddu, J.A. (2007) Completely Transvaginal NOTES Cholecystectomy Using Magnetically Anchored Instruments. Surgical Endoscopy, 21, 2308-2316. http://dx.doi.org/10.1007/s00464-007-9498-z

[60] Seven, R. and Barbaros, U. (2009) Needloscopy-Assisted Transvaginal Cholecystectomy. Surgical Laparoscopy, Endoscopy \& Percutaneous Techniques, 19, e61-e63. http://dx.doi.org/10.1097/SLE.0b013e31819caa22

[61] Sugimoto, M., Yasuda, H., Koda, K., Suzuki, M., Yamazaki, M., Tezuka, T., Kosugi, C., Higuchi, R., Watayo, Y., Yagawa, Y., Uemura, S., Tsuchiya, H., Hirano, A. and Ro, S. (2009) Evaluation for Transvaginal and Transgastric NOTES Cholecystectomy in Human and Animal Natural Orifice Translumenal Endoscopic Surgery. Journal of Hepato-Biliary-Pancreatic Surgery, 16, 255-260. http://dx.doi.org/10.1007/s00534-009-0090-X

[62] Zornig, C., Emmermann, A., Von Waldenfels, H.A. and Mofid, H. (2007) Laparoscopic Cholecystectomy without Visible Scar: Combined Transvaginal and Transumbilical Approach. Endoscopy, 39, 913-915. http://dx.doi.org/10.1055/s-2007-966911

[63] Zornig, C., Mofid, H., Emmermann, A., Alm, M., Von Waldenfels, H.A. and Felixmüller, C. (2008) Scarless Cholecystectomy with Combined Transvaginal and Transumbilical Approach in a Series of 20 Patients. Surgical Endoscopy, 22, 1427-1429. http://dx.doi.org/10.1007/s00464-008-9891-2

[64] Zornig, C., Mofid, H., Siemssen, L., Emmermann, A., Alm, M., Von Waldenfels, H.A. and Felixmüller, C. (2009) Transvaginal NOTES Hybrid Cholecystectomy: Feasibility Results in 68 Cases with Mid-Term Follow-Up. Endoscopy, 41, 391-394. http://dx.doi.org/10.1055/s-0029-1214644

[65] Zornig, C., Mofid, H., Emmermann, A., Alm, M., Waldenfels, H.A.V. and Felixmüller, C. (2009) Combined Transvaginal and Transumbilical Approach for Cholecystectomy with No Visible Scarring. Der Chirurg, 80, 364-369. http://dx.doi.org/10.1007/s00104-008-1648-x

[66] Zornig, C., Siemssen, L., Emmermann, A., Alm, M., Von Waldenfels, H.A., Felixmüller, C. and Mofid, H. (2011) NOTES Cholecystectomy: Matched-Pair Analysis Comparing the Transvaginal Hybrid and Conventional Laparoscopic Techniques in a Series of 216 Patients. Surgical Endoscopy, 25, 1822-1826. http://dx.doi.org/10.1007/s00464-010-1473-4

[67] Zorrón, R., Filgueiras, M., Maggioni, L.C., Pombo, L., Lopes Carvalho, G. and Lacerda Oliveira, A. (2007) NOTES Transvaginal Cholecystectomy: Report of the First Case. Surgical Innovation, 14, 279-283. http://dx.doi.org/10.1177/1553350607311090

[68] Zorron, R., Maggioni, L.C., Pombo, L., Oliveira, A.L., Carvalho, G.L. and Filgueiras, M. (2008) NOTES Transvaginal Cholecystectomy: Preliminary Clinical Application. Surgical Endoscopy, 22, 542-547. http://dx.doi.org/10.1007/s00464-007-9646-5

[69] Whang, S.H., Satgunam, S., Miedema, B.W. and Thaler, K. (2010) Transvaginal Cholecystectomy by Using a Prototype Flexible Clip Applier. Gastrointestinal Endoscopy, 72, 351-357. http://dx.doi.org/10.1016/j.gie.2010.02.050

[70] Wittich, A.C. (2007) Spilt Gallstones Removed after One Year through a Colpotomy Incision: Report of a Case. International Surgery, 92, 17-19.

[71] Buesing, M., Utech, M., Halter, J., Riege, R., Saada, G. and Knapp, A. (2011) Sleeve Gastrectomy in the Treatment of Morbid Obesity. Study Results and First Experiences with the Transvaginal Hybrid NOTES Technique. Der Chirurg, 82, 675-683. http://dx.doi.org/10.1007/s00104-010-1990-7

[72] Chouillard, E.K., Al Khoury, M., Bader, G., Heitz, D., Elrassi, Z. and Fauconnier, A., Intercontinental Society of Natural Orifice, Endoscopic, Laparoscopic Surgery (I-NOELS), Poissy, France (2011) Combined Vaginal and Abdominal Approach to Sleeve Gastrectomy for Morbid Obesity in Women: A Preliminary Experience. Surgery for Obesity and Related Diseases, 7, 581-586. http://dx.doi.org/10.1016/j.soard.2010.09.022

[73] Hagen, M.E., Wagner, O.J., Swain, P., Pugin, F., Buchs, N., Caddedu, M., Jamidar, P., Fasel, J. and Morel, P. (2008) Hybrid Natural Orifice Transluminal Endoscopic Surgery (NOTES) for Roux-En-Y Gastric Bypass: An Experimental Surgical Study in Human Cadavers. Endoscopy, 40, 918-924. http://dx.doi.org/10.1055/s-2008-1077720

[74] Lacy, A.M., Delgado, S., Rojas, O.A., Ibarzabal, A., Fernandez-Esparrach, G. and Taura, P. (2009) Hybrid Vaginal MA-NOS Sleeve Gastrectomy: Technical Note on the Procedure in a Patient. Surgical Endoscopy, 23, 1130-1137. http://dx.doi.org/10.1007/s00464-008-0292-3

[75] Ramos, A.C., Zundel, N., Neto, M.G. and Maalouf, M. (2008) Human Hybrid NOTES Transvaginal Sleeve Gastrectomy: Initial Experience. Surgery for Obesity and Related Diseases, 4, 660-663. http://dx.doi.org/10.1016/j.soard.2008.06.009

[76] Awad, Z.T., Qureshi, I., Seibel, B., Sharma, S. and Dobbertien, M.A. (2011) Laparoscopic Right Hemicolectomy with Transvaginal Colon Extraction Using a Laparoscopic Posterior Colpotomy: A 2-Year Series from a Single Institution. Surgical Laparoscopy, Endoscopy \& Percutaneous Techniques, 21, 403-408. http://dx.doi.org/10.1097/SLE.0b013e31823945ac 
[77] Burghardt, J., Federlein, M., Müller, V., Benhidjeb, T., Elling, D. and Gellert, K. (2008) Minimal Invasive Transvaginal Right Hemicolectomy: Report of the First Complex NOS (Natural Orifice Surgery) Bowels Operation Using a Hybrid Approach. Zentralblatt für Chirurgie, 133, 574-576. http://dx.doi.org/10.1055/s-2008-1076992

[78] Boni, L., Tenconi, S., Beretta, P., Cromi, A., Dionigi, G., Rovera, F., Dionigi, R. and Ghezzi, F. (2007) Laparoscopic Colorectal Resections with Transvaginal Specimen Extraction for Severe Endometriosis. Surgical Oncology, 16, 157160. http://dx.doi.org/10.1016/j.suronc.2007.10.003

[79] Diana, M., Perretta, S., Wall, J., Costantino, F.A., Leroy, J., Demartines, N. and Marescaux, J. (2011) Transvaginal Specimen Extraction in Colorectal Surgery: Current State of the Art. Colorectal Disease, 13, e104-e111. http://dx.doi.org/10.1111/j.1463-1318.2011.02599.x

[80] Dozois, E.J., Larson, D.W., Dowdy, S.C., Poola, V.P., Holubar, S.D. and Cima, R.R. (2008) Transvaginal Colonic Extraction Following Combined Hysterectomy and Laparoscopic Total Colectomy: A Natural Orifice Approach. Techniques in Coloproctology, 12, 251-254. http://dx.doi.org/10.1007/s10151-008-0428-4

[81] Franklin Jr., M.E., Kelley, H., Kelley, M., Brestan, L., Portillo, G. and Torres, J. (2008) Transvaginal Extraction of the Specimen after Total Laparoscopic Right Hemicolectomy with Intracorporeal Anastomosis. Surgical Laparoscopy, Endoscopy \& Percutaneous Techniques, 18, 294-298. http://dx.doi.org/10.1097/SLE.0b013e3181772d8b

[82] García Flórez, L.J., Argüelles, J., Quijada, B., Alvarez, V., Galarraga, M.A. and Graña, J.L. (2010) Transvaginal Specimen Extraction in a Laparoscopic Anterior Resection of a Sigmoid Colon Neoplasia with en Bloc Right SalpingoOophorectomy. Techniques in Coloproctology, 14, 161-163. http://dx.doi.org/10.1007/s10151-009-0561-8

[83] Karahasanoglu, T., Hamzaoglu, I., Aytac, E. and Baca, B. (2011) Transvaginal Assisted Totally Laparoscopic SinglePort Right Colectomy. Journal of Laparoendoscopic \& Advanced Surgical Techniques, 21, 255-257. http://dx.doi.org/10.1089/lap.2010.0438

[84] Lacy, A.M., Delgado, S., Rojas, O.A., Almenara, R., Blasi, A. and Llach, J. (2008) MA-NOS Radical Sigmoidectomy: Report of a Transvaginal Resection in the Human. Surgical Endoscopy, 22, 1717-1723. http://dx.doi.org/10.1007/s00464-008-9956-2

[85] Mckenzie, S., Baek, J.H., Wakabayashi, M., Garcia-Aguilar, J. and Pigazzi, A. (2010) Totally Laparoscopic Right Colectomy with Transvaginal Specimen Extraction: The Authors' Initial Institutional Experience. Surgical Endoscopy, 24, 2048-2052. http://dx.doi.org/10.1007/s00464-009-0870-z

[86] Palanivelu, C., Rangarajan, M., Jategaonkar, P.A. and Anand, N.V. (2008) An Innovative Technique for Colorectal Specimen Retrieval: A New Era of "Natural Orifice Specimen Extraction” (N.O.S.E). Diseases of the Colon \& Rectum, 51, 1120-1124. http://dx.doi.org/10.1007/s10350-008-9316-2

[87] Park, J.S., Choi, G.S., Lim, K.H., Jang, Y.S., Kim, H.J., Park, S.Y. and Jun, S.H. (2010) Clinical Outcome of Laparoscopic Right Hemicolectomy with Transvaginal Resection, Anastomosis, and Retrieval of Specimen. Diseases of the Colon \& Rectum, 53, 1473-1479. http://dx.doi.org/10.1007/DCR.0b013e3181f1cc17

[88] Park, J.S., Choi, G.S., Kim, H.J., Park, S.Y. and Jun, S.H. (2011) Natural Orifice Specimen Extraction versus Conventional Laparoscopically Assisted Right Hemicolectomy. British Journal of Surgery, 98, 710-715. http://dx.doi.org/10.1002/bjs.7419

[89] Sanchez, J.E., Rasheid, S.H., Krieger, B.R., Frattini, J.C. and Marcet, J.E. (2009) Laparoscopic-Assisted Transvaginal Approach for Sigmoidectomy and Rectocolpopexy. Journal of the Society of Laparoendoscopic Surgeons, 13, 217220.

[90] Tarantino, I., Linke, G.R., Lange, J., Siercks, I., Warschkow, R. and Zerz, A. (2011) Transvaginal Rigid-Hybrid Natural Orifice Transluminal Endoscopic Surgery Technique for Anterior Resection Treatment of Diverticulitis: A Feasibility Study. Surgical Endoscopy, 25, 3034-3042. http://dx.doi.org/10.1007/s00464-011-1666-5

[91] Torres, R.A., Orban, R.D., Tocaimaza, L., Vallejos Pereira, G. and Arévalo, J.R. (2012) Transvaginal Specimen Extraction after Laparoscopic Colectomy. World Journal of Surgery, 36, 1699-1702. http://dx.doi.org/10.1007/s00268-012-1528-x

[92] Yücesoy, A.N., Ercan Bülbül, E., Bahat, R., Cafer Köşkeroğlu, C. and Tsarkov, P.V. (2008) Transvaginal Low Anterior Resection for Rectal Cancer. Techniques in Coloproctology, 12, 83-86. http://dx.doi.org/10.1007/s10151-008-0403-0

[93] Jayaraman, S. and Schlachta, C.M. (2009) Transgastric and Transperineal Natural Orifice Translumenal Endoscopic Surgery (NOTES) in an Appendectomy Test Bed. Surgical Innovation, 16, 223-237. http://dx.doi.org/10.1177/1553350609342076

[94] Nezhat, C., Datta, M.S., Defazio, A., Nezhat, F. and Nezhat, C. (2009) Natural Orifice-Assisted Laparoscopic Appendectomy. Journal of the Society of Laparoendoscopic Surgeons, 13, 14-18.

[95] Palanivelu, C., Rajan, P.S., Rangarajan, M., Parthasarathi, R., Senthilnathan, P. and Prasad, M. (2008) Transvaginal Endoscopic Appendectomy in Humans: A Unique Approach to NOTES-World's First Report. Surgical Endoscopy, 
22, 1343-1347. http://dx.doi.org/10.1007/s00464-008-9811-5

[96] Pelosi III, M.A. and Pelosi, M.A. (1996) Vaginal Appendectomy at Laparoscopic-Assisted Vaginal Hysterectomy: A Surgical Option. Journal of Laparoendoscopic Surgery, 6, 399-403. http://dx.doi.org/10.1089/lps.1996.6.399

[97] Pérez, R.C., González, L.R., Reyes, E.D., Fernández, J.C., Arias, L.E. and Estrada, M.O. (2011) The Transvaginal Approach in Acute Appendicitis. Cirugía Española, 89, 517-523.

[98] Roberts, K.E., Solomon, D., Mirensky, T., Silasi, D.A., Duffy, A.J., Rutherford, T., Longo, W.E. and Bell, R.L. (2012) Pure Transvaginal Appendectomy versus Traditional Laparoscopic Appendectomy for Acute Appendicitis: A Prospective Cohort Study. Annals of Surgery, 255, 266-269. http://dx.doi.org/10.1097/SLA.0b013e31823b2748

[99] Shin, E.J., Jeong, G.A., Jung, J.C., Cho, G.S., Lim, C.W., Kim, H.C. and Song, O.P. (2010) Transvaginal Endoscopic Appendectomy. Journal of the Korean Society of Coloproctology, 26, 429-432. http://dx.doi.org/10.3393/jksc.2010.26.6.429

[100] Tabutsadze, T. and Kipshidze, N. (2009) New Trend in Endoscopic Surgery: Transvaginal Appendectomy NOTES (Natural Orifice Transluminal Endoscopic Surgery). Georgian Medical News, 168, 7-10.

[101] Alcaraz, A., Peri, L., Molina, A., Goicoechea, I., García, E., Izquierdo, L. and Ribal, M.J. (2010) Feasibility of Transvaginal NOTES-Assisted Laparoscopic Nephrectomy. European Urology, 57, 233-237. http://dx.doi.org/10.1016/j.eururo.2009.09.025

[102] Alcaraz, A., Musquera, M., Peri, L., Izquierdo, L., García-Cruz, E., Huguet, J., Alvarez-Vijande, R., Campistol, J.M., Oppenheimer, F. and Ribal, M.J. (2011) Feasibility of Transvaginal Natural Orifice Transluminal Endoscopic SurgeryAssisted Living Donor Nephrectomy: Is Kidney Vaginal Delivery the Approach of the Future? European Urology, 59, 1019-1025. http://dx.doi.org/10.1016/j.eururo.2011.03.021

[103] Aminsharifi, A., Taddayun, A., Shakeri, S., Hashemi, M. and Abdi, M. (2009) Hybrid Natural Orifice Transluminal Endoscopic Surgery for Nephrectomy with Standard Laparoscopic Instruments: Experience in a Canine Model. Journal of Endourology, 23, 1985-1989. http://dx.doi.org/10.1089/end.2009.0255

[104] Aron, M., Berger, A.K., Stein, R.J., Kamoi, K., Brandina, R., Canes, D., Sotelo, R., Desai, M.M. and Gill, I.S. (2009) Transvaginal Nephrectomy with a Multichannel Laparoscopic Port: A Cadaver Study. BJU International, 103, 15371541. http://dx.doi.org/10.1111/j.1464-410X.2009.08612.x

[105] Box, G.N., Lee, H.J., Santos, R.J., Abraham, J.B., Louie, M.K., Gamboa, A.J., Alipanah, R., Deane, L.A., Mcdougall, E.M. and Clayman, R.V. (2008) Rapid Communication: Robot-Assisted NOTES Nephrectomy: Initial Report. Journal of Endourology, 22, 503-506. http://dx.doi.org/10.1089/end.2007.0385

[106] Branco, A.W., Branco Filho, A.J., Kondo, W., Noda, R.W., Kawahara, N., Camargo, A.A., Stunitz, L.C., Valente, J. and Rangel, M. (2008) Hybrid Transvaginal Nephrectomy. European Urology, 53, 1290-1294. http://dx.doi.org/10.1016/j.eururo.2007.10.053

[107] Castillo, O.A., Vidal-Mora, I., Campos, R., Fonerón, A., Feria-Flores, M., Gómez, R. and Sepúlveda, F. (2009) Laparoscopic Simple Nephrectomy with Transvaginal Notes Assistance and the Use of Standard Laparoscopic Instruments. Actas Urológicas Españolas, 33, 767-770. http://dx.doi.org/10.1016/S0210-4806(09)74229-9

[108] Clayman, R.V., Box, G.N., Abraham, J.B., Lee, H.J., Deane, L.A., Sargent, E.R., Nguyen, N.T., Chang, K., Tan, A.K., Ponsky, L.E. and Mcdougall, E.M. (2007) Rapid Communication: Transvaginal Single-Port NOTES Nephrectomy: Initial Laboratory Experience. Journal of Endourology, 21, 640-644. http://dx.doi.org/10.1089/end.2007.0145

[109] Crouzet, S., Haber, G.P., Kamoi, K., Berger, A., Brethauer, S., Gatmaitan, P., Gill, I.S. and Kaouk, J.H. (2008) Natural Orifice Translumenal Endoscopic Surgery (NOTES) Renal Cryoablation in a Porcine Model. BJU International, 102, 1715-1718. http://dx.doi.org/10.1111/j.1464-410X.2008.07880.x

[110] Gettman, M.T., Lotan, Y., Napper, C.A. and Cadeddu, J.A. (2002) Transvaginal Laparoscopic Nephrectomy: Development and Feasibility in the Porcine Model. Urology, 59, 446-450. http://dx.doi.org/10.1016/S0090-4295(01)01568-0

[111] Gill, I.S., Cherullo, E.E., Meraney, A.M., Borsuk, F., Murphy, D.P. and Falcone, T. (2002) Vaginal Extraction of the Intact Specimen Following Laparoscopic Radical Nephrectomy. Journal of Urology, 167, 238-241. http://dx.doi.org/10.1016/S0022-5347(05)65423-7

[112] Isariyawongse, J.P., Mcgee, M.F., Rosen, M.J., Cherullo, E.E. and Ponsky, L.E. (2008) Pure Natural Orifice Transluminal Endoscopic Surgery (NOTES) Nephrectomy Using Standard Laparoscopic Instruments in the Porcine Model. Journal of Endourology, 22, 1087-1092. http://dx.doi.org/10.1089/end.2007.0404

[113] Kaouk, J.H., White, W.M., Goel, R.K., Brethauer, S., Crouzet, S., Rackley, R.R., Moore, C., Ingber, M.S. and Haber, G.P. (2009) NOTES Transvaginal Nephrectomy: First Human Experience. Urology, 74, 5-8. http://dx.doi.org/10.1016/j.urology.2009.03.030

[114] Kaouk, J.H., Haber, G.P., Goel, R.K., Crouzet, S., Brethauer, S., Firoozi, F., Goldman, H.B. and White, W.M. (2010) Pure Natural Orifice Translumenal Endoscopic Surgery (NOTES) Transvaginal Nephrectomy. European Urology, 57, 723-726. http://dx.doi.org/10.1016/j.eururo.2009.10.027 
[115] Perretta, S., Allemann, P., Asakuma, M., Cahill, R., Dallemagne, B. and Marescaux, J. (2009) Feasibility of Right and Left Transvaginal Retroperitoneal Nephrectomy: From the Porcine to the Cadaver Model. Journal of Endourology, 23, 1887-1892. http://dx.doi.org/10.1089/end.2008.0682

[116] Pietrabissa, A., Abelli, M., Spinillo, A., Alessiani, M., Zonta, S., Ticozzelli, E., Peri, A., Dal Canton, A. and Dionigi, P. (2010) Robotic-Assisted Laparoscopic Donor Nephrectomy with Transvaginal Extraction of the Kidney. American Journal of Transplantation, 10, 2708-2711. http://dx.doi.org/10.1111/j.1600-6143.2010.03305.x

[117] Porpiglia, F., Fiori, C., Morra, I. and Scarpa, R.M. (2011) Transvaginal Natural Orifice Transluminal Endoscopic Surgery-Assisted Minilaparoscopic Nephrectomy: A Step towards Scarless Surgery. European Urology, 60, 862-866. http://dx.doi.org/10.1016/j.eururo.2010.09.038

[118] Raman, J.D., Bergs, R.A., Fernandez, R., Bagrodia, A., Scott, D.J., Tang, S.J., Pearle, M.S. and Cadeddu, J.A. (2009) Complete Transvaginal NOTES Nephrectomy Using Magnetically Anchored Instrumentation. Journal of Endourology, 23, 367-371. http://dx.doi.org/10.1089/end.2008.0220

[119] Ribal Caparrós, M.J., Peri Cusí, L., Molina Cabeza, A., García Larrosa, A., Carmona, F. and Alcaraz Asensio, A. (2009) First Report on Hybrid Transvaginal Nephrectomy for Renal Cancer. Actas Urológicas Españolas, 33, $280-283$. http://dx.doi.org/10.1016/S0210-4806(09)74141-5

[120] Sánchez-Margallo, F.M., Pérez, F.J., Sánchez, M.A., Bachiller, J., Juárez, A., Serrano, A., Ribal, M.J. and Alcaraz, A. (2012) Transvaginal NOTES-Assisted Laparoscopic Nephrectomy: A Survival Study in a Sheep Model. Surgical Endoscopy, 26, 926-932. http://dx.doi.org/10.1007/s00464-011-1969-6

[121] Serrano-Ysern, A., Lopez, A., Mendez, F., Perez, L. and Acosta, J. (2008) Laparoscopic Nephrectomy with Laparoscopically Assisted Transvaginal Extraction of Intact Kidney. Boletín de la Asociación Médica de Puerto Rico, 100, 8185.

[122] Sotelo, R., De Andrade, R., Fernández, G., Ramirez, D., Di Grazia, E., Carmona, O., Moreira, O., Berger, A., Aron, M., Desai, M.M. and Gill, I.S. (2010) NOTES Hybrid Transvaginal Radical Nephrectomy for Tumor: Stepwise Progression toward a First Successful Clinical Case. European Urology, 57, 138-144. http://dx.doi.org/10.1016/j.eururo.2009.04.031

[123] Sotelo, R., Giedelman, C., Carmona, O., De Andrade, R. and Ramírez, D. (2011) Hybrid-NOTES Transvaginal HemiNephrectomy for Duplicated Renal Collecting System in the Adult Patient. Actas Urológicas Españolas, 35, 363-367. http://dx.doi.org/10.1016/j.acuro.2011.01.018

[124] Allemann, P., Perretta, S. and Marescaux, J. (2009) Surgical Access to the Adrenal Gland: The Quest for a "No Visible Scar” Approach. Surgical Oncology, 18, 131-137. http://dx.doi.org/10.1016/j.suronc.2008.12.005

[125] Almau Trenard, H., Mejias González, J. and Arellano Coraggio, J. (2011) Notes-Hybrid: Splenectomy (Transvaginal/ Umbilical). Acta Gastroenterologica Latinoamericana, 41, 221-224.

[126] Nakajima, K., Takahashi, T., Souma, Y., Shinzaki, S., Yamada, T., Yoshio, T. and Nishida, T. (2008) Transvaginal Endoscopic Partial Gastrectomy in Porcine Models: The Role of an Extra Endoscope for Gastric Control. Surgical Endoscopy, 22, 2733-2736. http://dx.doi.org/10.1007/s00464-008-0122-7

[127] Nakajima, K., Nishida, T., Takahashi, T., Souma, Y., Hara, J., Yamada, T., Yoshio, T., Tsutsui, T., Yokoi, T., Mori, M. and Doki, Y. (2009) Partial Gastrectomy Using Natural Orifice Translumenal Endoscopic Surgery (NOTES) for Gastric Submucosal Tumors: Early Experience in Humans. Surgical Endoscopy, 23, 2650-2655. http://dx.doi.org/10.1007/s00464-009-0474-7

[128] Noguera, J.F., Dolz, C., Cuadrado, A., Olea, J.M. and Vilella, A. (2008) Transvaginal Liver Resection (NOTES) Combined with Minilaparoscopy. Revista Española de Enfermedades Digestivas, 100, 411-415. http://dx.doi.org/10.4321/S1130-01082008000700006

[129] Perretta, S., Allemann, P., Asakuma, M., Dallemagne, B. and Marescaux, J. (2009) Adrenalectomy Using Natural Orifice Translumenal Endoscopic Surgery (NOTES): A Transvaginal Retroperitoneal Approach. Surgical Endoscopy, 23, 1390. http://dx.doi.org/10.1007/s00464-009-0367-9

[130] Targarona, E.M., Gomez, C., Rovira, R., Pernas, J.C., Balague, C., Guarner-Argente, C., Sainz, S. and Trias, M. (2009) NOTES-Assisted Transvaginal Splenectomy: The Next Step in the Minimally Invasive Approach to the Spleen. Surgical Innovation, 16, 218-222. http://dx.doi.org/10.1177/1553350609345488

[131] Truong, T., Arnaoutakis, D. and Awad, Z.T. (2012) Laparoscopic Hybrid NOTES Liver Resection for Metastatic Colorectal Cancer. Surgical Laparoscopy, Endoscopy \& Percutaneous Techniques, 22, e5-e7. http://dx.doi.org/10.1097/SLE.0b013e31823f7596

[132] Vereczkei, A., Illenyi, L., Arany, A., Szabo, Z., Toth, L. and Horváth, O.P. (2003) Transvaginal Extraction of the Laparoscopically Removed Spleen. Surgical Endoscopy, 17, 157. http://dx.doi.org/10.1007/s00464-002-4509-6

[133] Vettoretto, N., Balestra, L., Taglietti, L. and Giovanetti, M. (2010) Transvaginal Evisceration after Laparoscopic Adrenalectomy in Neurofibromatosis. Journal of Emergencies, Trauma, and Shock, 3, 204-205. 
http://dx.doi.org/10.4103/0974-2700.62107

[134] Zou, X., Zhang, G., Xiao, R., Yuan, Y., Wu, G., Wang, X., Long, D., Wu, Y., Liu, M., Xue, Y. and Zhang, X. (2011) Transvaginal Natural Orifice Transluminal Endoscopic Surgery (NOTES)-Assisted Laparoscopic Adrenalectomy: First Clinical Experience. Surgical Endoscopy, 25, 3767-3772. http://dx.doi.org/10.1007/s00464-011-1786-y 
Scientific Research Publishing (SCIRP) is one of the largest Open Access journal publishers. It is currently publishing more than 200 open access, online, peer-reviewed journals covering a wide range of academic disciplines. SCIRP serves the worldwide academic communities and contributes to the progress and application of science with its publication.

Other selected journals from SCIRP are listed as below. Submit your manuscript to us via either submit@scirp.org or Online Submission Portal.
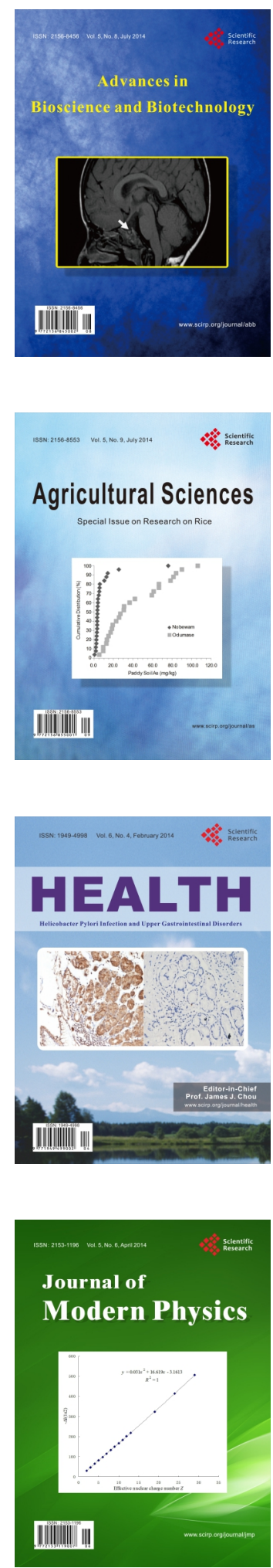
